V.V. Subbotina, V.V. Belozerov

\title{
The Effect of Electrolysis Conditions During Microarc Oxidation on the Phase-Structural State, Hardness and Corrosion Resistance of Magnesium Alloys
}

\author{
National technical university «Kharkiv polytechnic institute», Kharkiv, Ukraine subbotina.valeri@ gmail.com
}

\begin{abstract}
By the method of microarc oxidation for different types of electrolytes (which include $\mathrm{KOH}, \mathrm{Na}_{2} \mathrm{SiO}_{3}, \mathrm{H}_{2} \mathrm{O}_{2}$, $\mathrm{NaOH}, \mathrm{NaAlO}_{2}, \mathrm{Na}_{5} \mathrm{P}_{3} \mathrm{O}_{10}, \mathrm{NaF}$ ) and electrolysis conditions, multifunctional ceramic coatings on a magnesium alloy were obtained. The phase composition of the coating includes magnesium oxide ( $\mathrm{MgO})$, spinel $\mathrm{MgAl}_{2} \mathrm{O}_{4}$, $\mathrm{Mg}_{2} \mathrm{SiO}_{4}$ and $\mathrm{Mg}_{3}\left(\mathrm{PO}_{4}\right)_{2}$ compounds. The phase composition of the coatings is determined by the composition of the electrolyte. The obtained MAO coatings provide high hardness, which is 1500 to $7300 \mathrm{MPa}$, as well as high corrosion resistance. The results obtained make it possible to recommend MAO coatings on magnesium alloys both as an external (functional) layer and for the formation of an underlayer for the subsequent application of protective coatings (varnishes, polymers, polytetrafluoroethylene, in particular).

Keywords: microarc oxidation, ceramic coatings, alloy MA5, microstructure, x-ray phase analysis, microhardness, coating thickness, corrosion tests.
\end{abstract}

Received 21 August 2020; Accepted 15 September 2020.

\section{Introduction}

Low density, high specific strength and good machinability are the basis for the widespread use of magnesium alloys. The main reason that currently limits the scope of application of magnesium and its alloys is low corrosion resistance in atmospheric conditions, as well as in a humid environment of sea water [1]. The most common way to protect magnesium alloys against corrosion is by applying inorganic coatings in combination with paint, organic and metal coatings. However, at present, the problem of increasing corrosion resistance can be solved by a more productive and efficient method of microarc oxidation [2-4].

Microarc oxidation can significantly increase the corrosion resistance of valve metals ( $\mathrm{Al}, \mathrm{Mg}$ and $\mathrm{Ti}$ ) $[5,6]$.

This is especially important for Mg-based alloys, which have strong reduction properties [7-11].

Conducted research made it possible to establish that the microarc oxide coatings, which are formed on magnesium alloys, consist mainly of magnesium oxide and hydroxide and have different thicknesses and significant porosity [12]. Additives to electrolytes during the microarc process can contribute to the formation of continuous coatings. Therefore, numerous electrolytes during the microarc process differ in their components, due to which it is possible to increase the hardness of the coatings, reduce their porosity and improve other properties [13-15].

In this regard, it should be noted that today there are no unified approaches and principles in choosing the composition of the electrolyte and the oxidation regime. In each specific case, they are selected empirically. Therefore, a very important task for research is to study the kinetics and mechanisms of formation of MAO coatings on $\mathrm{Mg}$ and its alloys for different types of electrolytes, as well as the effect of processing conditions on the structure and properties of MAO coatings. This will increase the efficiency of MAO processing and expand the range of processed alloys [16, 17].

Therefore, the aim of this work was to study the effect of different types of electrolytes on the kinetics of oxidation, phase-structural state, and properties of MAO coatings formed on the widely used MA5 magnesium alloy. 


\section{Materials and methods}

The study was carried out on samples of MA5 alloys. The chemical composition of the alloys is given in Table 1.

Alloy MA5 refers to deformed magnesium alloys.

As electrolytes, solutions based on $\mathrm{KOH}$ and liquid glass with module 3 , which do not contain harmful substances were used. In some cases, sodium aluminate $\left(\mathrm{NaAlO}_{2}\right)$ and hydrogen peroxide $\mathrm{H}_{2} \mathrm{O}_{2}$ were added to the electrolyte as a component. In addition, electrolytes based on sodium aluminate $\mathrm{NaAlO}_{2}$, sodium hydroxide $\mathrm{NaOH}$, sodium heximethophosphate $\mathrm{Na}_{5} \mathrm{P}_{3} \mathrm{O}_{10}$ were studied.

To select the composition, preliminary studies were carried out on the initial process of «ignition» of spark discharges, which largely depends on the composition of the electrolyte. Thus, at a concentration of $1 \mathrm{~g} / \mathrm{l} \mathrm{KOH}$ without liquid glass in an electrolyte with a current density of $20 \mathrm{~A} / \mathrm{dm}^{2}$, small and weak discharges are ignited on the metal surface, and the coating is not formed. When $1 \mathrm{~g} / \mathrm{l}$ of liquid glass is added to the previous composition of the electrolyte, blue discharges are ignited first on the metal surface, which indicates the intense radiation of magnesium ions and $\mathrm{OH}$ radicals. After a certain time, green sparks appear in the discharges (radiation of atoms and magnesium ions). In this case, the coating is formed uneven, rough as a result of spark breakdowns and dissolution of the substrate metal and, ultimately, often peels off. At a concentration of liquid glass of $2 \mathrm{~g} / \mathrm{l}$ and $2-3 \mathrm{~g} / \mathrm{l}$ of $\mathrm{KOH}$, the discharge glow is bright and micro-arc discharges last a long time. Thus, observing the color of the discharges, their sizes and luminescence, the composition of electrolytes was selected, which is shown in Table 2.

Microarc oxidation was carried out in the anodiccathodic mode on an installation with a capacitor-type power supply [18]. The treatment time varied from 10 to 75 minutes at a current density of $20-40 \mathrm{~A} / \mathrm{dm}^{2}$.

The phase composition of the coating was determined from the diffractograms obtained on a DRON-3 diffractometer in $\mathrm{K}_{\alpha}-\mathrm{Cu}$ radiation. The survey was carried out in a point-by-point mode with a step of $2 \theta=0.1^{\circ}$. The quantitative content of the phases was determined by the method of quantitative X-ray analysis using a previously constructed calibration curve according to the data of standard mixtures.

The microhardness was determined using a PMT-3 device, the principle of which is based on the indentation of a diamond tip (pyramid) into the material under a certain load $(0.49-0.98 \mathrm{~N})$.

The coating thickness was determined using a VT-10 NTs vortex thickness gauge. The error in measuring the coating thickness is no more than $5 \%$ at the smallest coating thickness (about $10 \mu \mathrm{m}$ ).

Corrosion tests of MAO coatings were carried out by the drop method [19] and in a salt fog chamber. The reagent was a sodium chloride solution containing phenolphthalein. The time from the moment the drop is applied to the appearance of a pink color characterizes the protective properties of the coating; for cast magnesium alloys, the norm is 1 minute.

\section{Results and Discussion}

The main reason for the limited field of application of magnesium and its alloys is poor corrosion resistance due to the high value of its electronegative potential. Magnesium alloys are highly reactive and corrode at a noticeable rate during operation in atmospheric conditions.

Microarc oxidation allows to change the surface layer of products into a ceramic coating consisting of crystalline oxides and spinels.

As a result of this treatment, the surface layers of magnesium alloys are transformed into a ceramic coating, which consists of crystalline oxides and spinels. $\mathrm{X}$-ray phase analysis showed that the main phases of the coating are $\mathrm{MgO}, \mathrm{MgAl}_{2} \mathrm{O}_{4}, \mathrm{Mg}_{2} \mathrm{SiO}_{4}$, the quantitative

Table 1

Chemical composition of MA5 alloys

\begin{tabular}{|c|c|c|c|c|c|}
\hline Alloy & \multicolumn{3}{|c|}{ The main components, \% } & \multirow{2}{*}{ The amount of impurities } \\
\hline & $\mathrm{Mg}$ & $\mathrm{A} 1$ & $\mathrm{Mn}$ & $\mathrm{Zn}$ & 0.75 \\
\hline MA5 & the basis & $7.8-9.2$ & $0.15-0.50$ & $0.20-0.80$ & 0.75 \\
\hline
\end{tabular}

Table 2

The composition of the electrolytes used, the phase composition and the hardness of the coatings

\begin{tabular}{|c|c|c|c|c|c|c|c|}
\hline \multirow{2}{*}{ Electrolyte number } & \multicolumn{7}{|c|}{ Composition, g/l } \\
\cline { 2 - 8 } & $\mathrm{KOH}$ & $\mathrm{Na}_{2} \mathrm{SiO}_{3}$ & $\mathrm{H}_{2} \mathrm{O}_{2}$ & $\mathrm{NaOH}$ & $\mathrm{NaAlO}_{2}$ & $\mathrm{Na}_{5} \mathrm{P}_{3} \mathrm{O}_{10}$ & $\mathrm{NaF}$ \\
\hline 1 & 2 & 12 & - & - & - & - & - \\
\hline 2 & 3 & 2 & 2 & - & - & - & - \\
\hline 3 & - & - & - & 2.5 & 3 & 1 & - \\
\hline 4 & - & - & - & 2.5 & 3 & 3 & - \\
\hline 5 & - & - & - & 2.5 & 3 & 3 & 1.5 \\
\hline 6 & - & 50 & - & - & - & - & 1.5 \\
\hline 7 & - & 110 & - & - & - & - & 1.5 \\
\hline
\end{tabular}




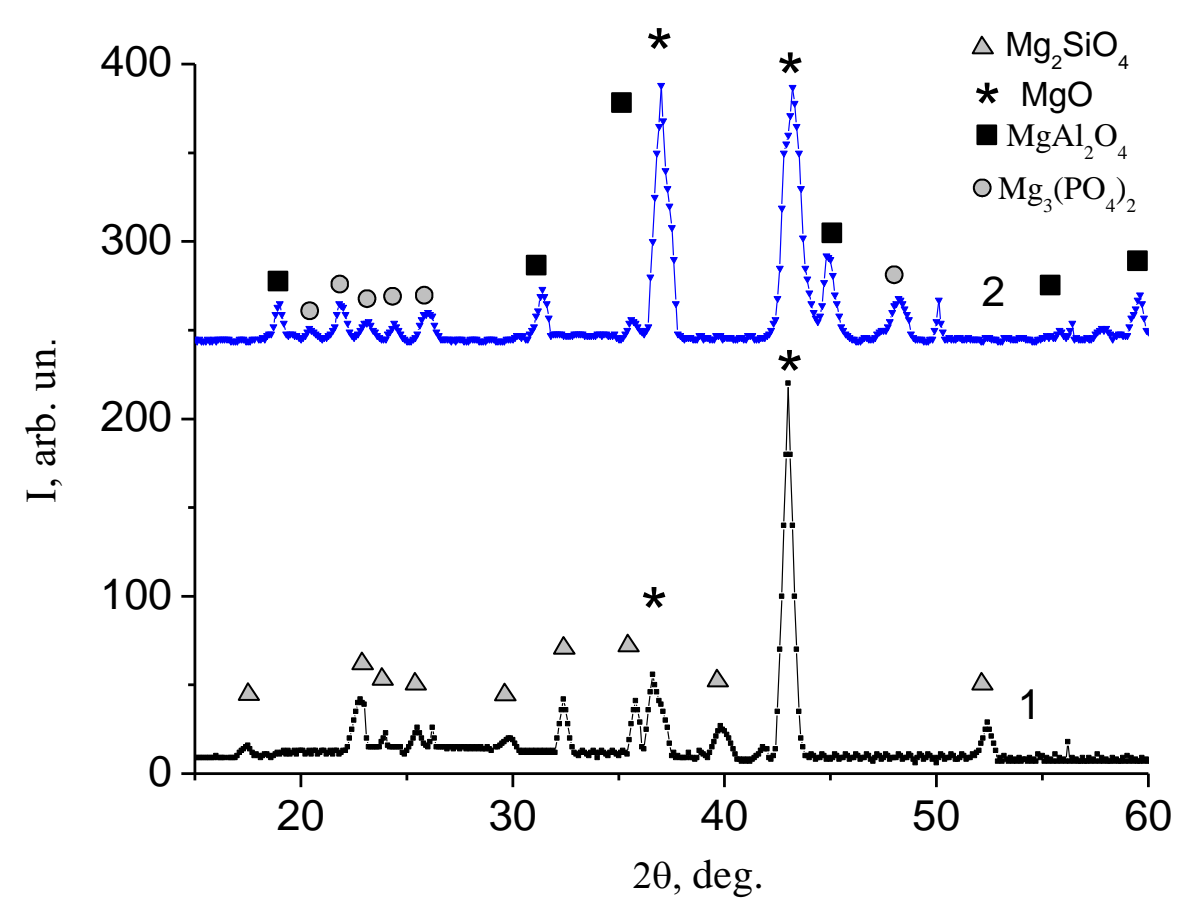

Fig. 1. Fragments of diffraction patterns $\left(\mathrm{K}_{\alpha}-\mathrm{Cu}\right)$ of MAO coatings (1 - electrolyte 1 ; 2 - electrolyte 5).

Table 3

Phase composition of MAO coatings on magnesium alloys obtained in various electrolytes

\begin{tabular}{|c|c|}
\hline Electrolyte & Phase composition of the coating \\
\hline 1 & $\mathrm{MgO}+\mathrm{Mg}_{2} \mathrm{SiO}_{4}$ \\
\hline 2 & $\mathrm{MgO}+\mathrm{Mg}_{2} \mathrm{SiO}_{4}$ \\
\hline 3 & $\mathrm{MgO}+\mathrm{MgAl}_{2} \mathrm{O}_{4}$ \\
\hline 4 & $\mathrm{MgO}+\mathrm{MgAl}_{2} \mathrm{O}_{4}+\mathrm{Mg}_{3}\left(\mathrm{PO}_{4}\right)_{2}$ \\
\hline 5 & $\mathrm{MgO}+\mathrm{MgAl}_{2} \mathrm{O}_{4}+\mathrm{Mg}_{3}\left(\mathrm{PO}_{4}\right)_{2}$ \\
\hline 6 & $\mathrm{Halo}+\mathrm{MgO}+\mathrm{Mg}_{2} \mathrm{SiO}_{4}$ \\
\hline 7 & $\mathrm{Halo}+\alpha-\mathrm{SiO}_{2}+\mathrm{MgO}+\mathrm{Mg}_{2} \mathrm{SiO}_{4}$ \\
\hline
\end{tabular}

ratio between which is determined by the composition of the electrolyte and the electrolysis parameters (processing time and current density).

Typical diffraction patterns of coatings are shown in Fig. 1. They indicate that the phases have a crystalline structure. The phase composition of MAO coatings obtained at different compositions of electrolytes is shown in Table 3.

It should be noted that in electrolytes where $\mathrm{Na}_{2} \mathrm{SiO}_{3}$ is present in the composition of coatings, the $\mathrm{MgO}$ and $\mathrm{Mg}_{2} \mathrm{SiO}_{4}$ phases are revealed (Table 3). These are electrolytes 1, 2, 6, 7 (the composition of the electrolyte is indicated in Table 2).

In electrolytes with sodium aluminate $\mathrm{NaAlO}_{2}$, coatings are formed, which include the $\mathrm{MgO}$ and $\mathrm{MgAl}_{2} \mathrm{O}_{4}$ phases. The main phase is the $\mathrm{MgO}$. In the coatings obtained in electrolytes 1 and 2, the content of the $\mathrm{Mg}_{2} \mathrm{SiO}_{4}$ phase varies from 15 to $27 \%$. In the coatings obtained in electrolyte $3, \mathrm{MgAl}_{2} \mathrm{O}_{4}$ with a content of 14 vol \% appears as the second component. The addition of $\mathrm{Na}_{5} \mathrm{P}_{3} \mathrm{O}_{10}$ as a constituent of the electrolyte (with a content of $3 \mathrm{~g} / \mathrm{l}$ ) leads to a 3-phase state of coatings of the 4th type (Table 3 ).

The addition of the 4 th component $(\mathrm{NaF})$ to the electrolyte 5 leads to an increase in the relative content of $\mathrm{MgAl}_{2} \mathrm{O}_{4}$ to 24 vol. $\%$, and $\mathrm{Mg}_{3}\left(\mathrm{PO}_{4}\right)_{2}$ to 10 vol. $\%$.

The use of a high content of liquid glass in electrolytes 6 and 7 is accompanied by the appearance of a halo-like component in the diffraction spectra. This is due to the formation of a very finely dispersed phase under the action of silicon [20]. For these types of electrolytes, $\mathrm{MgAl}_{2} \mathrm{O}_{4}$ and $\mathrm{Mg}_{2} \mathrm{SiO}_{4}$ are identified as accompanying phases.

The second important characteristic of MAO 


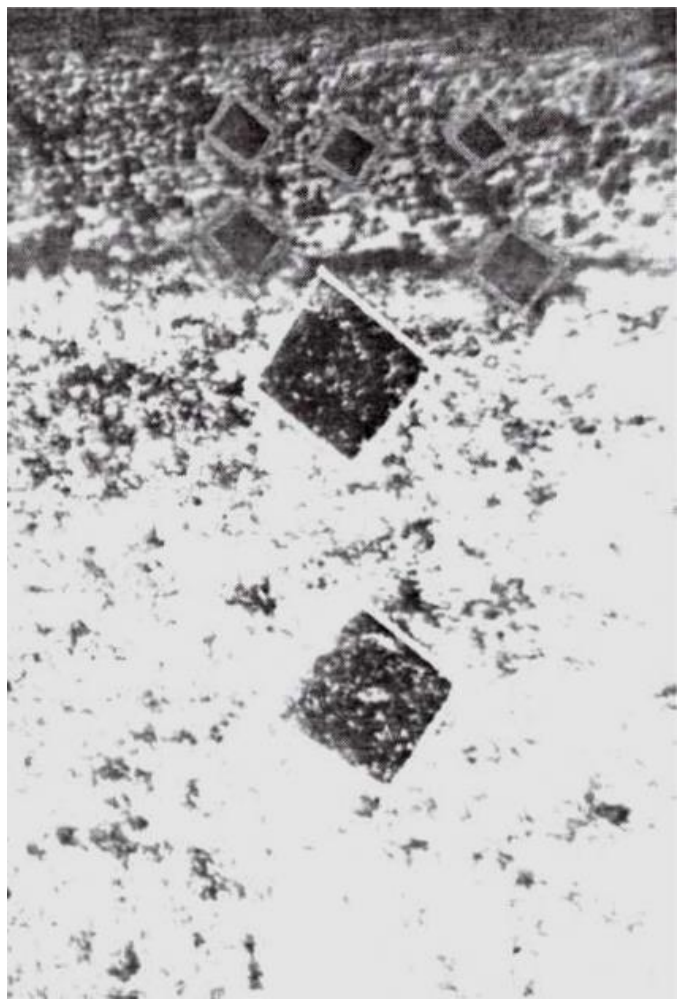

a

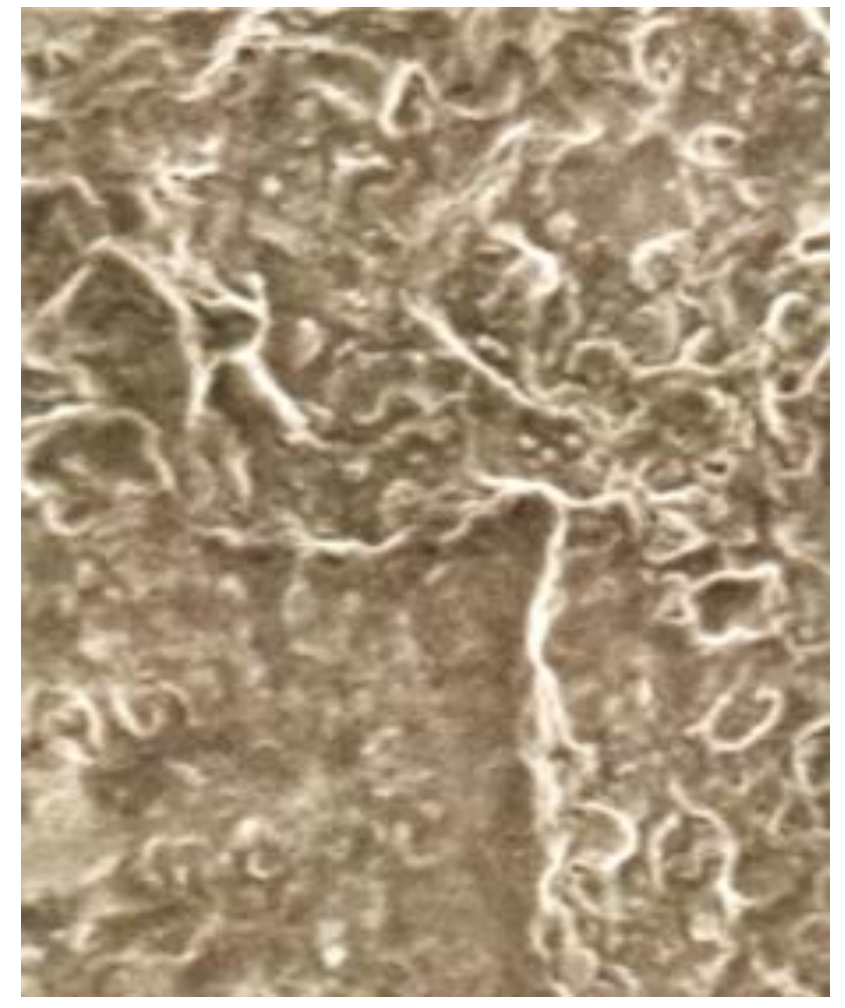

b

Fig. 2. Cross section (a) and surface (b) of magnesium alloy with MAO-coating obtained in electrolyte 5 (x 300).

coatings is their microstructure. Fig. 2 shows the microstructure of magnesium alloys with MAO coating (cross section). The coating thickness is determined by the electrolyte composition and the oxidation mode. Different modes of MAO are characterized by different forms of the interface. When a coating is formed in the mode of microarc discharges, the interface is practically rectilinear (Fig. 2a). If, during the formation of the coating, arc discharges are present, then in this case the interface acquires a cellular-wave character. It should be noted that the presence of arc discharges is accompanied by the formation of through pores, which, of course, worsens the corrosion resistance of the coatings; therefore, the appearance of arc discharges should be avoided.

For clarity of the transition «base material - MAOcoating» Fig. 2 shows the imprints of microhardness both in the base alloy layer (lower) and in the MAO-coating (upper).

The surface of the coatings (Fig. 2b) is heterogeneous with the presence of discontinuities. This type of surface is typical for MAO coatings on a magnesium alloy, formed with all types of electrolytes used. With a large thickness of coatings (more than 50 $\mu \mathrm{m})$, microcracks are revealed on their surface.

The appearance of such micro-cracks may be due to the fact that the specific volume of the coating is less than that of the base. For comparison, the specific volumes of the phases were calculated using the formula:

$$
\Delta=\left(\mathrm{M}_{\mathrm{o}} \mathrm{d}_{\mathrm{m}} / \mathrm{M}_{\mathrm{m}} \mathrm{d}_{\mathrm{o}}\right),
$$

where Mo is the molecular weight of the oxide, $M_{m}$ is the atomic weight of the metal, $d_{m}$ and $d_{o}$ are the specific weight of the metal and oxide.

The calculation showed that for $\mathrm{MgO}$ and $\mathrm{Mg}$ the value of $\Delta$ is 0.8 ; for $\mathrm{MgAl}_{2} \mathrm{O}_{4}$ and $\mathrm{Mg}$, the value of $\Delta$ is 2.84, and for $\mathrm{Mg}_{2} \mathrm{SiO}_{4}$ and $\mathrm{Mg}$, the value of $\Delta$ is 1.49.

Thus, the calculation showed that the formation of MAO coatings on magnesium alloys with the main $\mathrm{MgO}$ phase, the volume of which is smaller in comparison with $\mathrm{Mg}$, is accompanied by the appearance of tensile stresses, can stimulate the formation of cracks in the coating.

A natural way to reduce tensile stresses is to increase the specific volume of the coating. This can be achieved by forming spinel-type oxides in the coating structure. Thus, the specific volume of $\mathrm{MgAl}_{2} \mathrm{O}_{4}$ oxides is 2.84 times higher than the specific volume of $\mathrm{Mg}$, and the specific volume of $\mathrm{Mg}_{2} \mathrm{SiO}_{4}$ oxide is also 1.49 times higher than the specific volume of magnesium. Thus, the formation of a multiphase coating will contribute to a decrease in tensile stresses in the coating and a transition to compressive stresses.

The third important characteristic of MAO coatings is the kinetics of their growth and the effect of electrolysis conditions on it.

Fig. 3 shows the results of the study of the effect of the MAO process time in different electrolytes on the thickness of the formed coatings.

The data shown in Fig. 3 in comparison with the composition of electrolytes (Table 2) show that an increase in the composition of the electrolyte of hydrogen peroxide and sodium silicate contributes to an 
increase in the growth rate.

The highest rate of growth is provided by electrolyte 5, which, in addition to alkali and sodium aluminate $\left(\mathrm{NaAlO}_{2}\right)$, includes sodium hexamethophrsfate $\left(\mathrm{Na}_{5} \mathrm{P}_{3} \mathrm{O}_{10}\right)$. Electrolyte 2 ( $3 \mathrm{~g} / \mathrm{K} \mathrm{KOH}, 2 \mathrm{~g} / 1 \mathrm{Na}_{2} \mathrm{SiO}_{3}$, and $2 \mathrm{~g} / \mathrm{l} \mathrm{H}_{2} \mathrm{O}_{2}$ ) also provides a high growth rate.

Thus, analyzing the results obtained, it can be concluded that by appropriate selection of the electrolyte, it is possible to increase the growth rate of MAO coatings on magnesium alloys from $25 \mu \mathrm{m} / \mathrm{h}$ to $190 \mu \mathrm{m} / \mathrm{h}$, which makes the formation of coatings 200 $300 \mu \mathrm{m}$ thick efficient.

The most universal method for testing the mechanical properties of a surface is measuring its hardness. The hardness of MAO coatings (obtained in different electrolytes) on magnesium alloys is presented

\section{in Table 4.}

As can be seen from the presented results, coatings obtained in electrolyte $1\left(\mathrm{KOH}+\mathrm{Na}_{2} \mathrm{SiO}_{3}\right)$ are characterized by a rather high growth rate, but the hardness of such coatings does not exceed $1600 \mathrm{MPa}$. The addition of $\mathrm{H}_{2} \mathrm{O}_{2}$ (electrolyte 2) stimulates an increase in the $\mathrm{Mg}_{2} \mathrm{SiO}_{4}$ content from 15 to 27 vol. \%. This leads to an increase in hardness up to $2800 \mathrm{MPa}$. The hardness of the coating obtained in in this case is already different $\left(\mathrm{MgO}+\mathrm{MgAl}_{2} \mathrm{O}_{4}\right)$. For coatings obtained in type 4 electrolyte 3 , a significant increase in the growth rate (Table 4, Fig. 3) did not lead to high hardness (the highest hardness is $1810 \mathrm{MPa}$ ).

The highest hardness was achieved in coatings obtained in type 5 electrolytes. In these coatings, the content of the $\mathrm{MgAl}_{2} \mathrm{O}_{4}$ phase and $\mathrm{Mg}_{3}\left(\mathrm{PO}_{4}\right)_{2}$ crystallites

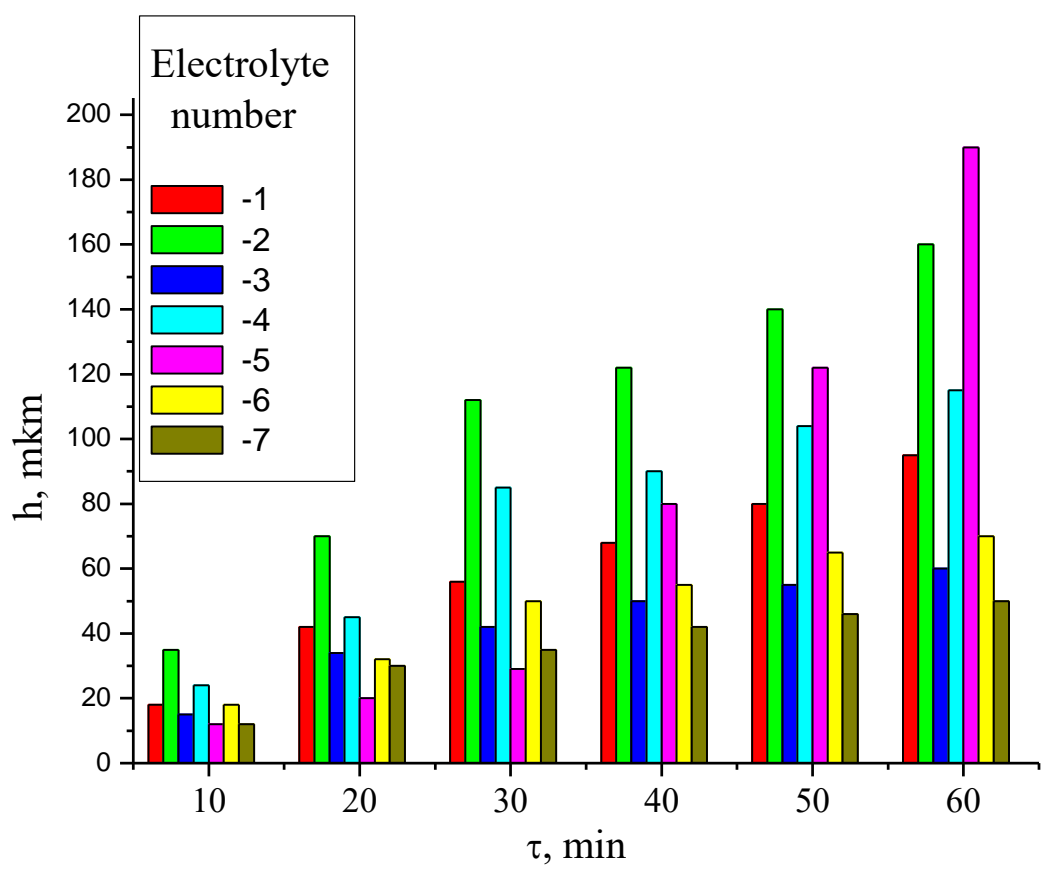

Fig. 3. Dependence of the coating thickness on the duration of oxidation

Table 4

Effect of oxidation parameters on the thickness and hardness of MAO coatings

\begin{tabular}{|c|c|c|c|}
\hline \multirow{2}{*}{ Electrolyte number } & Process time, $\tau, \min$ & Thickness, $\mathrm{h}, \mu \mathrm{m}$ & Hardness, HV, MPa \\
\hline \multirow{2}{*}{1} & 30 & 56 & 1180 \\
\cline { 2 - 4 } & 60 & 95 & 1600 \\
\hline \multirow{2}{*}{2} & 30 & 112 & 2600 \\
\hline \multirow{2}{*}{3} & 60 & 160 & 2800 \\
\cline { 2 - 4 } & 30 & 42 & 2700 \\
\hline \multirow{2}{*}{4} & 60 & 60 & 2850 \\
\cline { 2 - 4 } & 20 & 45 & 1680 \\
\hline \multirow{2}{*}{5} & 30 & 85 & 1700 \\
\hline \multirow{2}{*}{6} & 60 & 115 & 3360 \\
\hline 7 & 30 & 25 & 7350 \\
\hline
\end{tabular}


is increased (Fig. 1, spectrum 2). It should be noted that the obtained value of the coating hardness is almost 13 times higher than the hardness of the base alloy material (600 MPa).

The use of silicide components in electrolytes of the 6th and 7th types, although it leads to a multiphase crystalline state (table 3 ), however, the hardness of such coatings does not exceed $3300 \mathrm{MPa}$.

Thus, MAO treatment of a magnesium alloy provides the formation of coatings, the hardness of which is 3 - 13 times higher than the hardness of the base $(\mathrm{HV}=$ $600 \mathrm{MPa})$.

To determine the corrosion resistance of the coatings, the drop method was used in the work, and a $\mathrm{NaCl}$ solution containing phenolphthalein served as the reagent.

As studies have shown, the highest durability (195 sec) was shown by coatings obtained in electrolyte 5 (Table 2). The coatings obtained in electrolytes of the 6th and 7 th types also showed greater durability (more than $100 \mathrm{sec}$ ). In electrolytes 1,2 , and 3 , the durability is somewhat lower, which can be associated with the defectiveness of the coatings (the presence of through pores and cracks, which is a consequence of the lower specific volume of the coating compared to the base). Such coatings are under the action of tensile stresses, which increases its defectiveness and reduces corrosion resistance.

Thus, the high development of the surface and the relatively high hardness make it possible to use MAO coatings both as an external (functional) layer and as a sublayer to further improve corrosion resistance by applying other protective coatings (varnishes, paints, polymers, etc.), while ensuring their good adhesion.

\section{Conclusion}

1. The possibility of using MAO for the formation of oxide coatings up to $200 \mu \mathrm{m}$ thick on magnesium alloys has been established. The selected compositions of electrolytes and the electrolysis modes were established, which ensure the growth rate of MAO coatings of 50 $200 \mu \mathrm{m} / \mathrm{h}$.

2. It was found that as a result of MAO treatment, ceramic coatings are formed, in which such phases as magnesium oxide $(\mathrm{MgO})$, spinel $\mathrm{MgAl}_{2} \mathrm{O}_{4}, \mathrm{Mg}_{2} \mathrm{SiO}_{4}$ and $\mathrm{Mg}_{3}\left(\mathrm{PO}_{4}\right)_{2}$ compounds are formed. The phase composition of the coatings is determined by the composition of the electrolyte. It was found that the main phase is magnesium oxide $\mathrm{MgO}$.

3. It is shown that as a result of MAO treatment of magnesium alloys, a rough surface is formed. To prevent the appearance of microcracks in such coatings, it was proposed to saturate it with the $\mathrm{MgAl}_{2} \mathrm{O}_{4}$ and $\mathrm{Mg}_{2} \mathrm{SiO}_{4}$ phases, which have a larger specific volume than the base material.

4. The electrolysis conditions used in the work ensure high hardness, which is 1500 to $7300 \mathrm{MPa}$, which is 3-13 times higher than the hardness of the base $(600 \mathrm{MPa})$, as well as high corrosion resistance, which exceeds the standard.

5. The highest hardness $7300 \mathrm{MPa}$ and corrosion resistance are inherent in coatings obtained in a complex electrolyte $\left(2.5 \mathrm{~g} / \mathrm{l} \mathrm{NaOH}, 3 \mathrm{~g} / 1 \mathrm{NaAlO}_{2}, 3 \mathrm{~g} / \mathrm{l} \mathrm{Na} 5 \mathrm{P}_{3} \mathrm{O}_{10}\right.$, $1.5 \mathrm{~g} / \mathrm{NaF}$ ) whose phase composition includes crystallites of 3 phases: $\mathrm{MgO}, \mathrm{MgAl}_{2} \mathrm{O}_{4}$ and $\mathrm{Mg}_{3}\left(\mathrm{PO}_{4}\right)_{2}$.

6. The results obtained make it possible to recommend MAO coatings on magnesium alloys both as an external (functional) layer and for the formation of an underlayer for the subsequent application of protective coatings (varnishes, polymers, in particular, polytetrafluoroethylene).

Subbotina V.V. - Candidate of technical sciences, Associate Professor, Department of Materials science; Belozerov $\boldsymbol{V} . \boldsymbol{V}$. - Professor, Candidate of technical sciences, Associate Professor, Department of Materials science.

[1] Y. Gu, X. Cai, Y. Guo, C. Ning, Mater design 43, 542 (2013) (https://doi.org/10.1016/j.matdes.2012.07.049).

[2] R. Arrabal, E. Matykina, T. Hashimoto, P. Skeldon, G. E. Thompson, Surface and coatings technology 203(16), 2207 (2009) (https://doi.org/10.1016/j.surfcoat.2009.02.011).

[3] G.-H. Lv, H. Chen, L. Li, E.-W. Niu, H. Pang, B. Zou, S.-Z. Yang, Current applied physics 9(1), 126 (2009) (https://doi.org/10.1016/j.cap.2007.12.007).

[4] H. Luo, Q. Cai, B. Wei, B. Yu, D. Li, J. He, Z. Liu, Journal of alloys and compounds 464(1-2), 537 (2008) (https://doi.org/10.1016/j.jallcom.2007.10.072).

[5] V.J Kharanagh, M.A.F. Sani, E. Rafizadeh, Surface engineering 30(3), $224 \quad$ (2014) (https://doi.org/10.1179/1743294413Y.0000000190).

[6] Z. P Yao, D. L. Wang, Q.X. Xia, Y.J. Zhang, Z.H. Jiang, F.P. Wange, Surface engineering 28(2), 96 (2012) (https://doi.org/10.1179/1743294411Y.0000000045).

[7] D.Y. Hwang, Y.M. Kim, D. Park, B. Yoo, and D.H. Shin, Electrochimica acta 54(23), 5479 (2009) (https://doi.org/10.1016/j.electacta.2009.04.047).

[8] U Malayoglu, K.C. Tekin, S. Shrestha, Surface \& coatings technology 205(6), 1793 (2010) (https://doi.org/10.1016/j.surfcoat.2010.08.022).

[9] R.O Hussein, D.O Northwood, X. Nie, Surface \& coatings technology 237, 357 (2013) (https://doi.org/10.1016/j.surfcoat.2013.09.021).

[10] Y. Mori, A. Koshi, J. Liao, H. Asoh, S. Ono, Corrosion science 88, 254 (2014) (https://doi.org/10.1016/j.corsci.2014.07.038). 
[11] L.R. Krishna, G. Poshal, G. Sundararajan, Metallurgical and materials transactions A 41(13), 3499 (2010) (http://dx.doi.org/10.1007/s11661-010-0412-2).

[12] S. Durdu, S. Bayramoglu, A. Demirtaş, M. Usta, A.H. Üçışık, Vacuum 88, 130 (2013) (https://doi.org/10.1016/j.vacuum.2012.01.009).

[13] A. Mandelli, M. Bestetti, A.Da Forno, N. Lecis, S.P. Trasatti, M.A. Trueba, Surface \& coatings technology 205(19), 4459 (2011) (https://doi.org/10.1016/j.surfcoat.2011.03.06).

[14] R.O. Hussein, P. Zhang, X. Nie, Y. Xia, D.O. Northwood, Surface \& coatings technology 206(7), 1990 (2011) (https://doi.org/10.1016/j.surfcoat.2011.08.060).

[15] H. Chen, J.M. Hao, D.X. Li, L.P. Li, Advanced materials research 236-238, 1954 (2011) (https://doi.org/10.4028/www.scientific.net/AMR.236-238.1954).

[16] P. Su, X. Wu, Y. Guo, Z. Jiang, Journal of alloys and compounds 475(1-2), 773 (2008) (https://doi.org/10.1016/j.jallcom.2008.08.030).

$\begin{array}{llllll} & \text { [17] P. Su, X. Wu, } & \text { Z. Jiang, } & \text { Materials } & \text { Letters }\end{array}$ (https://doi.org/10.1016/j.matlet.2008.02.023).

[18] V. Belozerov, O. Sobol, A. Mahatilova, V. Subbotina, T.A. Tabaza, U.F. Al-Qawabeha, S.M. Al-Qawabah, Eastern-european journal of enterprise technologies 5(12-89), 52 (2017) (https://doi.org/10.15587/17294061.2017.112065).

[19] V. Belozerov, A. Mahatilova, O. Sobol', V.a Subbotina, A. Subbotin, Eastern-european journal of enterprise technologies 2(5-86), 39 (2017) (https://doi.org/10.15587/1729-4061.2017.96721).

[20] V. Subbotina, O. Sobol, V. Belozerov, U.F. Al-Qawabeha, T.A. Tabaza, S.M. Al-Qawabah, V. Shnayder, Eastern-european journal of enterprise technologies 3(12-105), 6 (2020) (https://doi.org/10.15587/17294061.2020.205474).

В.В. Субботіна, В.В. Білозеров

\title{
Вплив умов електролізу при мікродуговому оксидуванні на фазово- структурний стан, твердість і корозійну стійкість магнієвих сплавів
}

\author{
Національний технічний університет «Харківський політехнічний інститут», Харків, Україна, \\ subbotina.valeri@gmail.com
}

\begin{abstract}
Методом мікродугового оксидування для різних типів електролітів (до складу яких включені КОН, $\mathrm{Na}_{2} \mathrm{SiO}_{3}, \mathrm{H}_{2} \mathrm{O}_{2}, \mathrm{NaOH}, \mathrm{NaAlO}_{2}, \mathrm{Na}_{5} \mathrm{P}_{3} \mathrm{O}_{10}, \mathrm{NaF}$ ) і умов електролізу отримані багатофункціональні керамічні покриття на магнієвому сплаві. Фазовий склад покриття включає оксид магнію $(\mathrm{MgO})$, шпінель $\mathrm{MgAl}_{2} \mathrm{O}_{4}$, 3'єднання $\mathrm{Mg}_{2} \mathrm{SiO}_{4}$ i $\mathrm{Mg}_{3}\left(\mathrm{PO}_{4}\right)_{2}$. Фазовий склад покриттів визначається складом електроліту. Отримані МДО-покриття забезпечують високу твердість, яка становить від 1500 до 7300 МПа, а також високу корозійну стійкість. Отримані результати дозволяють рекомендувати МДО-покриття, отримані на магнієвих сплавах, як в якості зовнішнього (функціонального) шару, так і для формування подслою для подальшого нанесення захисних покриттів (лаків, полімерів, зокрема політетрафторетилену).

Ключові слова: мікродугове оксидування, керамічні покриття, сплав МА5, мікроструктура, рентгеноструктурний фазовий аналіз, мікротвердість, товщина покриття, корозійні випробування.
\end{abstract}

